\title{
Organizational Values and Trust: Determining Factors in Organizational Civism Behaviors
}

\author{
Fabiana Rocha Dias ${ }^{1}$ \\ Faculdades Integradas Pitágoras, Uberlândia, MG, Brazil \\ Áurea de Fátima Oliveira \\ Instituto de Psicologia da Universidade Federal de Uberlândia, Uberlândia, MG, Brazil
}

\begin{abstract}
This study aimed to verify the impact of organizational values and trust on civism behaviors. Participants were 206 employees from several organizations, who responded to reliable and valid instruments related to each construct: Inventory of Organizational Values Profile, Inventory Employee Trust in the Organization and Civism Scale in Organizations. The reliability coefficients of the scales for the study sample were higher than .70, thus they allowed the inclusion of all the variables in the standard multiple regression analysis. The factors of organizational civism were the dependent variables, whereas the organizational values and the factors of trust composed the independent variables. The results demonstrated the trust in ethics and organizational competence and the organizational values of conformity, autonomy and collectivity were predictors of the organizational civism dimensions. The conclusion of the study indicates the importance of those variables in the emission of organizational Civism behaviors, while also suggesting the performance of studies with other samples and the inclusion of new variables for future investigations.
\end{abstract}

Keywords: Civism behaviors, organizational values, trust.

\section{Valores e Confiança Organizacionais: Fatores Determinantes nos Comportamentos de Civismo Organizacional}

\section{Resumo}

Este estudo teve como objetivo verificar o impacto de valores e confiança organizacionais sobre comportamentos de civismo. Participaram do estudo 206 trabalhadores, de diversas organizações, que responderam a instrumentos fidedignos e válidos referentes a cada construto: Inventário de Perfis de Valores Organizacionais, Inventário de Confiança do Empregado na Organização e Escala de Civismo nas Organizações. Os coeficientes de confiabilidade das escalas para a amostra do estudo foram superiores a 0,70, permitindo a inclusão de todas as variáveis nas análises de regressão múltipla padrão. As variáveis dependentes foram os fatores de civismo organizacional enquanto as independentes foram os valores organizacionais e os fatores de confiança. Os resultados mostraram que confiança na ética e na competência organizacional e os valores organizacionais conformidade, autonomia e coletividade foram preditores das dimensões de civismo organizacional. A conclusão do estudo indica a importância dessas variáveis na emissão de comportamentos de civismo organizacional, sugerindo, ainda, a realização de estudos abrangendo outras amostras bem como a inclusão de novas variáveis em modelos de investigação futuros.

Palavras-chave: Civismo organizacional, valores organizacionais, confiança.

Mailing address: Rua Paraná, 812, Bairro Brazil, Uberlândia, MG, Brazil 38400-654.E-mail: fabianarochadias@ gmail.com 


\section{Los Valores Organizacionales y de Confianza: Factores Determinantes en el Comportamiento de la Civilidad Organizacional}

\section{Resumen}

Este estudio tuvo como objetivo verificar el impacto de los valores y de confianza en la organización en los comportamientos de civismo. Participaron del estudio 206 trabajadores, de varias organizaciones, que respondieron a instrumentos fidedignos y validos referentes a cada constructo: Inventario de los valores de la organización Perfil, la confianza de los empleados de inventario en la Escala de Organización y civilidad en las Organizaciones. Los coeficientes de confiabilidad de las escalas para la muestra del estudio fueron superiores a .70, permitiendo la inclusión de todas las variables en los análisis de regresión múltiple estándar. Las variables dependientes fueron los factores de civismo organizacional mientras las independientes fueron los valores organizacionales y los factores de confianza. Los resultados mostraron que la confianza en la ética y en la competencia organizacional sumada a los valores organizacionales de conformidad, autonomía y colectividad predijeron las dimensiones de civismo organizacional. La conclusión del estudio enseña la importancia de estas variables en la emisión de comportamientos de civismo organizacional, sugiriendo, sin embargo, la realización de estudios abarcando otras muestras así como la inclusión de nuevas variables en modelos futuros de investigación.

Palabras clave: Civismo organizacional, valores organizacionales, confianza.

Organizational citizenship behaviors have been studied since 1980, even though such behaviors are not explicitly recognized by the formal reward system (Cavazotte, Hartman, \& Bahiense, 2013; Chhetri, 2014). This interest can be attributed to their importance in relation to the achievement of organizational goals, contributing to its effectiveness. Among the many benefits of citizenship behaviors, Rauf (2014) describes client satisfaction, quality and quantity of goods and services, as well as the return in sales percentages.

Organ, in 1990, defined organizational citizenship behaviors as informal contributions that people can give to or withhold from the organization, free from the possibility of sanctions or formal incentives. Therefore, they emerge independent of rules or remuneration that the individual can receive. That is, they are behaviors that go beyond what is determined by the organizations, through which workers can cooperate spontaneously with their work organization and colleagues (Bastos, Siqueira, \& Gomes, 2014; Siqueira, 1995).

Since these behaviors contribute to organizational results (Rauf, 2014), it is necessary to identify which variables can have an impact on their occurrence, as this knowledge may be useful for organizational strategies, as well as for policies and staff management practices. This study aimed to investigate the role played by the perception of organizational values - as the core of the organizational culture - and of the trust of the employee in the organization in the determination of the Organizational Civism. This concept was suggested by Siqueira (1995) to replace the Organizational Citizenship Behaviors who, after analysis of the work of Katz and Kahn (1974), concluded that these behaviors did not concern the rights and duties of the workers. Therefore, according to Siqueira (1995), the transposition of the term for the work context would not be appropriate.

Later, Porto and Tamayo (2005, p. 37) defined the Organizational Civism construct as "spontaneous behaviors of the workers that benefit the organizational system". In the international literature the expression Organizational Citizenship still dominates, and, in most studies, the theoretical approach allows comparisons with organizational civism.

Cavazotte and colleagues (2013) and Dolan, Tzafrir and Baruch (2005), believe that Citizenship Behaviors can be encouraged 
or restricted by cultural factors, such as the fact that the expression of altruistic behaviors are more likely in collectivist cultures than in individualistic cultures. Dolan and colleagues add that managers must consider the real culture when they think about the emission of these behaviors by employees.

Among the perspectives of investigation of culture, Tamayo (2007) highlights the importance of the values in determining the behavior of employees, as well as in the allocation of resources. For these authors, organizational values are shared and supported within organizations, especially those that are perceived by employees as being effectively characteristic of the organization. According to this author, organizational values are principles or beliefs shared by the employees that guide their behavior and the functioning of the organization. They indicate the choices made by the organization through its history, being expressed by behaviors, quality standards, organizational structures and management strategies, among other things.

Trust, the second component of the model, is an essential attribute in the relationships established between groups or organizations that they aspire to preserve beyond the present (Siqueira \& Gomide, 2014). Organizational trust plays a critical role that can determine the preservation or rupture of the relationship between the employees and the organization in which they operate (Batista \& Oliveira, 2012; Nienaber, Hofeditz, \& Searle, 2014).

Chhetri (2014) assumes the connection between citizenship behavior, justice and organizational trust, explaining that the interdependence among the members of an organization is only possible when there is trust between them. Thus, trust is deposited by the employees in their employers thanks to the possibility of formulating policies that can affect the citizenship behavior.

The definition of Organizational Trust as a set of beliefs related to organizational ethical standards, to limited use of opportunism in the relationships and to competence that is revealed in the technical capacity and financial strength of the organization (Ianaguivara, 2011). This concept will be adopted in this study, where the focus of analysis focuses on aspects of the organization perceived by the employees.

Previous studies have correlated organizational values and civism (Jardim, 2009; Porto \& Tamayo, 2003, 2005); and organizational values and trust (Guardani, Teixeira, Bido, \& Mazzon, 2013; Oliveira, 2004; Oliveira \& Souza, 2014). However, according to the literature, there are few studies that have linked these variables in an integrated model of investigation. Given the above, this study aimed to investigate the impact of organizational values and employee trust in the organization on civism behaviors. Its importance lies in the fact that managers should be aware of the need to create cultural systems and relationships based on trust capable of facilitating the emission of behaviors beneficial to the organization that can affect both individual performance and that of the organization itself (Dolan et al., 2005; Guardani et al., 2013; Purohit, Patel, \& Purohit, 2014).

\section{Organizational Civism Behaviors}

The origin of Organizational Civism Behaviors has its premises in the concept of Organizational Citizenship referring to the perspective of Katz and Kahn (1974). For these authors it is necessary for organizations to foster in their members the desire to be and remain part of them, while their attitudes and results comply fully with what is expected of each person and they contribute new ideas and improvements for the organizations. It is postulated that this desire needs to arise from both the organization and the people.

Moorman (1991) also made contributions by indicating that acts of citizenship can be seen as information and service resources. In this sense, the behavior of citizenship would be a form of social reciprocation of members of the organization when there is a fair exchange in this relationship.

According to Siqueira (1995), the term organizational citizenship received criticism regarding its relevance to describe the behaviors represented. In fact, the term Citizenship 
expresses, on one hand, submission to authority and on the other, the exercise of rights. Thus, the analysis conducted by the author suggests that such a concept does not refer to the rights of the workers nor to their duties, but to the behaviors performed by the employees for their organization, while being under no obligation to carry them out (Siqueira, 1995). Considering the use of this term in the workplace inadequate to describe spontaneous behaviors, the author suggested the expression Organizational Civism.

The concept became the study target of Porto and Tamayo (2003), who constructed and validated the Organizational Civism Scale, having the earlier work of Siqueira (1995) as the reference. This study proposed a new scale, composed of the same factors and with higher indices of reliability. For these authors, Organizational Civism is defined as spontaneous acts of the workers that benefit the organizational system, allowing specific forms of manifestation, although without formal remuneration being provided by the organization (Porto \& Tamayo, 2003).

In the international literature, the term Organizational Citizenship continues to be used as in previous decades, attracting the attention of researchers investigating its antecedents and consequences. Among the antecedent variables, recent studies reinforce the role of organizational justice (Asamani \& Mensah, 2013; Lee, Kim, \& Kim, 2013), of the quality of working life (Kashani, 2012), of the effect of personality, of organizational commitment, of job satisfaction and of the perception of organizational support on organizational citizenship behaviors and their implications for individual and organizational performance (Hakim, Nimram, Haerani, \& Alam, 2014); and management skills (Rapp, Bachrach, \& Rapp, 2013).

\section{Organizational Trust}

The importance of organizational trust is associated with the links established by the individual with his/her work organization, since the contracts and formal controls are not the only means available to keep the peace in the relation- ships within the organizations (Kramer, 1999; Oliveira \& Tamayo, 2008). During work activities, individuals seek to establish social relationships that can generate security and recognition for the work performed. Thus, trust arises as the basis of social interaction that provides means of obtaining this security, even if it is not complete and present at all times (Oliveira \& Tamayo, 2008).

In the concept of Cummings and Bromiley (1996), organizational trust refers to the individual belief or common belief among a group of people in another individual or group, leading them (individual or group) to make efforts of good faith to behave in accordance with the commitment made explicitly or implicitly, to be honest in any negotiations that precede the commitment and to not take excessive advantage of the other (individual or group) when the opportunity occurs. (p. 303).

This concept covers both the individual's trust in his group, as well as the trust between organizational units.

Oliveira (2004), in turn, suggests a definition for trust, founded in cognitive theory, by proposing that the concept refers to a set of interdependent cognitions that include beliefs about ethical standards, credibility in the communication and in the economic power of the organization beyond the belief in its ability to recognize the performance of the employee. This definition clarifies that the trust existing in the organization is perceived by individuals when they direct their efforts aiming to associate and process the information resulting from this context.

Guided by the same principles, Ianaguivara (2011) proposed that organizational trust refers to a set of beliefs related to the ethical standards of the organization, to limited use of opportunism in the relationships and to competence that is revealed in the technical capacity and financial strength of the organization (Ianaguivara, 2011). This concept of trust provided the foundation for the construction of the scale to be used in this study.

The investigation of trust from the perspective of individuals in relation to their 
work organization proves useful as new management models judged secure lose their stability. Given this reality, there is a need for alternative pathways that allow balance in the relationship between employee and employer (Zanini, Lusk, \& Wolff, 2009).

According to Oliveira and Souza (2014), the scientific literature on trust in the organizational context has grown in recent years. This can be illustrated with some studies relating this construct to variables such as organizational management (Drummond, 2007; Novelli, Fischer, \& Mazzon, 2006); cooperative behavior (Ferrin, Bligh, \& Kohles, 2007) organizational commitment (Chhetri, 2014; Song \& Kim, 2009); organizational citizenship (Cavazotte et al., 2013; Chhetri, 2014; Hakim et al., 2014; Hassan \& Semerciöz, 2010); job satisfaction (Hakim et al., 2014; Leat \& El-Kot, 2009); and personal and organizational values (Oliveira \& Souza, 2014).

\section{Organizational Values}

According to Silva and Zanelli (2014), culture, from the ethnographic perspective, refers to knowledge, belief, art, morals, law, custom and other capabilities and habits acquired by man as a social being. In the organizational context, the comprehension of organizational processes permeates the issue of culture. The importance attached to certain values by an organization can determine the amount of effort invested by its members in the emission of certain behaviors, as well as the persistence in their execution (Tamayo, 2008).

Interest in the study of organizational values has increased in recent years due to an understanding of the centrality of this concept when it comes to organizational culture (Carvalho, Oliveira, \& Silva, 2013). In Brazil, quantitative studies on organizational values have frequently been conducted. The findings indicate the relationship of values with commitment (Ferreira \& Fernandes, 2009), organizational practices and client trust in the service sector (Guardani et al., 2013), organizational trust (Oliveira \& Souza, 2014) and civism (Jardim, 2009; Porto \& Tamayo, 2005). Added to this is the bibliometric study conducted by Estivalete, Andrade, Gomes and Costa (2012), based on a survey of articles on organizational values published between 2002 and 2011 in the events of the National Association of Graduate Programs in Administration (ANPAD) and in periodicals of the Management Area, which identified 46 articles on the topic. In the international literature, the studies of Cavazotte et al. (2013), Moorman and Blakely (1995) and Spitzmüller, Van Dyne and Remus (2008) have related cultural aspects to organizational citizenship behaviors.

The function of the values is to direct the organizational life and guide the behavior of its members, outlining the way the people act, think and judge (Jardim, 2009; Tamayo, 2008; Tamayo \& Gondim, 1996). The values, the origin of which is in social interaction, are constructed from the work needs and, over time, constitute differentiating organizational elements, making them unique, different from the others (Hassan, 2007).

Oliveira and Tamayo (2004) point out that organizational values act as mediators in conflicts, contributing to the solution of organizational problems and play an important role in achieving the organizational objectives and in meeting the needs of the individuals. The values explain the cultural dimension that encourages researchers to understand the organizational culture and to modify it to suit the requirements of the organizational environment (Oliveira \& Gomide, 2012).

The literature consulted subsidizes the hypothesis that organizational values and the trust of the employee in the organization have an impact on civism behaviors. The perception of organizational values and a relationship based on trust can create a favorable environment for behaviors that are not formally prescribed and not rewarded by the system. Such behaviors, when stimulated, can compose one of the competitive advantages for organizations.

\section{Method}

The sample consisted of 200 workers linked to organizations, of which $61 \%$ were female, 
$37 \%$ male and $2 \%$ did not provide this information. The education level ranged from complete high school to graduate education, with participants with incomplete higher education $(79.5 \%)$ and linked to private organizations $(86.5 \%)$ predominating. The age of the participants ranged from 18 to 49 years with a mean of 27 years $(S D=7.04)$ and mean time working in the company of 3 years $(S D=3.86)$. The calculation of the test power, carried out through the GPower program for indication of the sample size, was used, considering the mean effect $\left(f^{2}=.15 ; p<\right.$ $.05)$, which indicated that 178 subjects would be required.

The project was approved by the Research Ethics Committee of the Institution (CAAE No. 21682013.0.0000.5152). The data collection procedure safeguarded the identity of the participants who were approached in public places: at the door of the school, in the companies, universities, squares and at bus stops. A place and time for completing the questionnaire was agreed between the researcher and the consenting subjects. Only those who met the inclusion criteria of being employed in a formal organization for more than six months and having completed elementary education composed the sample.

The study instruments used in data collection were: (a) Profile of Organizational Values Inventory - IPVO (Oliveira \& Tamayo, 2004) - composed of the factors Realization (the focus is on valorization, from the organization, planning and collective and individual competence), Conformity (how much the organization appreciates good manners, courtesy, respect for the rules of coexistence, correction and hierarchy), Domination (the central goal is to obtain profits, control over people and resources), Tradition (preserving customs and organizational practices) Employee Well-being (the focus of the organization is to promote employee satisfaction, paying attention to the quality of working life), Autonomy (the organization seeks to perfect its employees and its products and services), Organizational Prestige (the organization seeks admiration and respect from society through the quality of its products and services) and Concern with the Collective (values that promote justice and equality at work and tolerance, sincerity and honesty), the reliability indices (Cronbach's Alpha) of which ranged from .75 to .87 . The items were evaluated on a six point scale $(0=$ is nothing like my organization, $5=$ is very similar to my organization). In the validation study, the authors used analysis of the main axes, oblique rotation and factor loadings greater than .35 , with the final instrument explaining $46.48 \%$ of the variance. (b) Trust of the Employee in the Organization Inventory (Ianaguivara, 2011) - composed of the factors Trust in Ethics (use of ethical standards in the relationship with clients and employees), Trust in Competence (the organization knows and dominates the technologies in the area of practice better than other organizations, making it efficient in its performance) and Opportunism (the organization seeks to take advantage of its employees and clients through the use of manipulation or taking advantage of mistakes and weaknesses), with the reliability ranging from .84 to .96 . In the validation study, the authors used analysis of the main axes, oblique rotation and factor loadings greater than .50 , with the final instrument explaining $49.64 \%$ of the variance. (c) Organizational Civism Scale (Porto \& Tamayo, 2003), composed of the factors Creative Suggestions for the System (behavior of employees regarding the suggestion of new ideas to the management to benefit the organization), Protection of the System (actions aimed at ensuring the assets of the organization) Creation of Favorable Climate (behaviors of dissemination of the advantages and merits of the organization outside the workplace), Self-training (behavior of employees in seeking courses and events that improve their performance at work) and Cooperation with Colleagues (spontaneous behavior of help for co-workers), the items of which are evaluated on a Likert scale of five points $(1=$ never; $5=$ always). Cronbach's alpha ranged from .80 to .91. In the validation study, the authors used analysis of the main axes, oblique rotation and factor loadings greater than .45 , with the final instrument explaining $45 \%$ of the variance. 
Regarding the reliability of the instruments, the Cronbach's alpha values were all greater than .70 , being evaluated as satisfactory (Hair, Anderson, Tatham, \& Black, 2005).

Data analyzes were performed using SPSS (Statistical Package for Social Science), version 19. Exploratory data analysis was performed in order to verify data input errors, eliminate extreme univariate and multivariate values and replace missing data for the mean of the sample, considering the percentage of these data was less than 5\% (Tabachnick \& Fidell, 2001). The sample was described using descriptive statistics (mean, standard deviation and frequency). The model test, in turn, was performed through multiple regression analysis in order to determine which variables would be the best predictor of organizational civism behaviors.

\section{Results}

Initially the assumptions necessary for the application of multivariate statistical techniques were verified. The normality of the distribution was tested by the Kolmogorov-Smirnov method and presented significance. Next, the analysis of the histograms with overlay of the standard curve and of the asymmetry indices indicated that both remained within acceptable parameters according to the requirements of Miles and Shevlin (2001). In addition to the normality, the reliability of each of the factors of the instruments was tested for the sample studied through Cronbach's Alpha calculation, showing results close to the original studies (i.e. values greater than .70), indicating acceptable reliability (Hair et al., 2005).

Five standard regressions were calculated, with the factors of organizational values and employee trust as the explanatory variables (Table $1)$. The model of Creative Suggestions for the System was explained in $22 \%$, adjusted $R^{2}=.18$, $F(11,187)=4.919, p<.001$. The beta coefficients indicate that Trust in the Ethics $(\beta=.47$; $p=.001)$ was a stronger predictor than the Collectivity value $(\beta=-.28 ; p=.032)$ in explaining Creative Suggestions. Considering the hypothesis of suppression, as the bivariate correlations between the Collectivity and Creative Suggestions value was positive $(r=.21 ; p=.001)$ and the Beta negative, another regression analysis was calculated without this variable. The results indicated Trust in the Ethics, $\beta=.36, p=.003$; $R^{2}=.20, F(10,188)=4.848 ; p<.001$, and the Realization value $(\beta=-.24, p=.043)$ as significant predictors. It was found, through another regression analysis, that when Trust in the Ethics was eliminated from the model, the Collectivity value did not present a significant contribution, revealing only the Autonomy value $(\beta=.31 ; p$ $=.004)$ as a regressor. Thus, it seems more appropriate to consider Trust in the Ethical Components as the predictor of Creative Suggestions, assuming the hypothesis of suppression.

The model related to the Protection of the System explained $31 \%$ of the variance of the model, adjusted $R^{2}=.27 ; F(11,187)=7.720$; $p<.001$, having the Conformity value $(\beta=.33$; $p=.001)$ and Trust in the Organizational Competence $(\beta=.22 ; p=.044)$ as predictors. Creation of a Favorable Climate, the third model tested, presented the following predictors in order of importance: Trust in the Ethics $(\beta=.33$; $p=.001)$, Trust in the Competence $(\beta=.25 ; p$ $=.004)$ and the Autonomy value $(\beta=.24 ; p=$ $.027)$. The model explained $57 \%$ of the variance, adjusted $R^{2}=.55, F(11,187)=22.954, p<.001$, with the other variables eliminated.

The final two models retained single and distinct predictors, being the Autonomy value in the case of Self-training, $\beta=.40 ; p=.006$; adjusted $R^{2}=.23, F(11,187)=6.397, p<.001$. Regarding Cooperation with Colleagues, the predictor was the Conformity value, $\beta=.20, p$ $=.041$; adjusted $R^{2}=.21, F(11,187)=5.840$; $p<.001$.

\section{Discussion}

The results presented indicate that organizational values and employee trust predict organizational civism. Trust in Ethics and Organizational Competence predict Creative Suggestions for the System, Protection of the System and Favorable Climate for the Organization in the External Environment. In turn, the Conformity 
Table 1

Summary of Standard Multiple Regression Analyzes for the Criterion Variables Related to Organizational Civism

\begin{tabular}{|c|c|c|c|c|c|c|}
\hline $\begin{array}{l}\text { Criterion } \\
\text { Variable }\end{array}$ & Predictors & $B$ & $\beta$ & multiple $R$ & model $R^{2}$ & adjusted $R^{2}$ \\
\hline \multirow[t]{2}{*}{ Creative suggestions } & $\begin{array}{l}\text { Trust } \\
\text { Ethics }\end{array}$ & $.52 * * *$ & $.47 * * *$ & .47 & .22 & .18 \\
\hline & OV Collectivity & $-.24 *$ & $-.28 *$ & & & \\
\hline \multirow[t]{2}{*}{ Protection for the system } & OV Conformity & $.22 * * *$ & $.33 * * *$ & .56 & .31 & .27 \\
\hline & $\begin{array}{c}\text { Trust } \\
\text { Competence }\end{array}$ & $.19^{*}$ & $.22 *$ & & & \\
\hline \multirow[t]{3}{*}{ Favorable climate } & OV Autonomy & $.19^{*}$ & $.24 *$ & .75 & .57 & .55 \\
\hline & $\begin{array}{c}\text { Trust } \\
\text { Competence }\end{array}$ & $.34 * *$ & $.25 * *$ & & & \\
\hline & $\begin{array}{l}\text { Trust } \\
\text { Ethics }\end{array}$ & $.37 * * *$ & $.33 * * *$ & & & \\
\hline Self-training & OV Autonomy & $.37 * *$ & $.40 * *$ & .52 & .27 & .23 \\
\hline $\begin{array}{l}\text { Cooperation with } \\
\text { colleagues }\end{array}$ & OV Conformity & $.22 *$ & $.20^{*}$ & .51 & .26 & .21 \\
\hline
\end{tabular}

Note. OV=Organizational Values.

$* p<.05, * * p<.01, * * * p<.001$.

value contributes to predicting Cooperation with Colleagues and Protection of the System while the Autonomy value predicts Self-training and Creating a Favorable Environment for the Organization in the External Environment. Among the eight types of values only these presented significant contributions.

Employee trust in the ethical principles that guide the organization manifests itself given honest and loyal relationships, transparency of the organization to disclose information, maintenance of obligations, and the willingness to consider the interests and common good of the employees. Once the employees put their trust in their work organization they are likely to emit behaviors, such as suggesting new and creative ideas to the management, aiming to contribute its improvement. Similarly, the employees may divulge the advantages and merits of their organization outside of the work environment, promoting its positive image.
These behaviors are based on a relationship of social exchange in which both parties contribute and obtain benefits. The bond of trust is only established when this social exchange is configured, which stimulates the emission of spontaneous behaviors that are not contractually expected, however, benefit the organization.

Trust in organizational competence refers to the belief of the employees in the technical dominance, updating and economic strength of the organization. When the employee nurtures this belief, the results indicate that behaviors are emitted that are directed toward the protection of the system through actions that preserve the assets. Trust in the competence of the organization also implies believe that it will resist crises and continue to exist because it is financially and technically sound. From these beliefs the behavior of employees in disseminating externally a positive image of the organization is explained. 
The Autonomy value, in turn, also contributes to Creating a Favorable Climate for the Organization in the External Environment, since its goals are related to seeking constant perfection of the employee and organization, valorizing competence, creativity and challenges. According to Porto and Tamayo (2005), if people realize that their organization values autonomy, they tend to emit behaviors more favorable for the organization externally, promoting the positive image of the organization in the market. In management terms, those organizations that have policies and practices of stimulating autonomy provide the consonance between organizational and individual goals.

The behaviors of Self-training refer to the actions of employees that seek learning opportunities to improve their performance at work. These actions lead to the acquisition of new skills and knowledge, which is of interest to the organization, as it will have professionals qualified for the work. The emission of these behaviors depends on an environment in which the Autonomy value predominates, indicating that the organization has, among its goals, the valorization of competence and creativity. The results obtained corroborate those of studies that indicate the relationship between organizational citizenship behaviors and productivity at the level of the unit, profitability, efficiency and turnover (Podsakoff, Whiting, Podsakoff, \& Blume, 2009; Podsakoff, Whiting, Podsakoff, \& Mishra, 2011). In this case, the organizational culture, by facilitating spontaneous employee development, generates concrete results, improving and benefiting the organization. Ozer (2011), when investigate the relationship between citizenship behaviors and work performance, found that $\mathrm{Au}$ tonomy is an important predictor, as it increases the ability of employees to incorporate the help they receive from their colleagues into their activities, positively influencing the performance of the employees in their tasks.

The Conformity value, in turn, refers to the limits of organizational actions and behaviors of its members, prioritizing respect for rules and models of behavior, both in the workplace and in the relationships with other organizations. Given the guidelines of the organization, the employee can emit behaviors that are protective towards the system, such as taking care of equipment and ensuring hygienic conditions of the working environment (Porto \& Tamayo, 2005). Protection for the System is also the result of Trust in the Organizational Competence, because the organization is recognized by the employee as having knowledge, technology and financial strength.

Cooperation with Colleagues covers spontaneous behaviors of helping co-workers. The meaning of cooperating is compatible with the definition proposed by Organ, Podsakoff, and MacKenzie (2006) when they report that behaviors of help refers to voluntary help from others, in order to prevent the occurrence of work-related problems. The value related to Conformity through its characteristics models of behavior, rules and definition of limits - contributes to cooperation in the work relationships, as the roles and expectations have a more clearly defined outline. Thus, the employees know when they can effectively cooperate with their colleagues. This behavior, not expected by the system, is valuable, as it improves the social environment and the performance of the work.

The results of this study show similarities with studies already cited, which found significant correlations between Civism and Values, Civism and Trust, and Values and Organizational Trust (Almeida \& Ferreira, 2010; Guardani et al., 2013; Horta, Demo, \& Roure, 2012; Jardim, 2009; Ozer, 2011; Podsakoff et al., 2009; Podsakoff et al., 2011). Thus, this study confirms results of studies that indicate the importance of Values and Organizational Trust in predicting Organizational Civism.

\section{Conclusions}

This study aimed to investigate the impact of values and organizational trust on organizational civism behaviors. In summary, the findings showed that Trust in the Ethics of the company predicted Creative Suggestions 
for the System while Trust in the Competence predicted Protection of the System and Creating a Favorable Climate for the Organization in the External Environment. Of the set of values investigated, Autonomy predicted Favorable Climate and Self-training, and Conformity predicted Protection of the System and Cooperation with Colleagues.

This study contributes to integrating, in a research model, variables previously studied in isolation related to the organizational civism behaviors. Thus, the literature on the subject gains more clarity to identify trust as a triggering factor for these behaviors, as it is a manifestation of a relationship of social exchange that encourages the employees in a way that is not defined by the employers. The literature suggests that the employee-organization relationship is characterized by high level of trust, with it being expected that employees emit civism behaviors.

The contribution of organizational culture, investigated by means of the values, indicates its influence on these behaviors. In addition to the organizational values perceived by the employees, there is a need to broaden the cultural knowledge of the organizations through analysis of documents and the study of the perceptions of the leaders.

The relevance of knowledge related to the antecedents of civism behaviors highlights the role of managers, as they can encourage such behaviors (Dolan et al., 2005). The creation of a reliable management system is discussed by Dolan and colleagues, who associate this system with human resource practices, such as recruitment and selection of personnel, remuneration and the career system.

From the managerial perspective, the consequences of the knowledge generated in this study refer to organizational planning directed toward the goals of the organization, however, considering its main asset: the staff. Employees who share the values of the organization create a mental representation of it that can influence attitudes such as job satisfaction, organizational commitment and civism behaviors.

On the other hand, trust in the organizational ethics and competence translates into beliefs of the employee regarding integrality, maintenance of commitments and the ability of the organization to accomplish what is proposed in relation to its employees and clients. The association between shared values and a trusting relationship, which implies the reduction of conflicts, makes the employee feel more secure and willing to cooperate with the organization. The organization, in turn, benefits from behaviors not prescribed, such as those of organizational civism.

It is believed that this knowledge can be applied to the area of Staff Management, generating information for the planning and adequate management of people. If the organization encourages civism behaviors this may lead to the employees being more involved in the work, more cooperative and willing to improve their skills and making efforts aimed at achieving organizational results.

Further studies are suggested, with the inclusion of other variables, such as human resource policies, and attitudinal variables, such as job satisfaction and organizational commitment, which could mediate the behaviors of civism. The importance of investigating the consequences of organizational civism is emphasized, given its relevance. Furthermore, there is a need for studies with different samples, as this study used a convenience sample specific for one region of the country.

\section{References}

Almeida, S. P., \& Ferreira, M. C. (2010). O impacto das atitudes frente às mudanças organizacionais nos comportamentos de cidadania. Psicologia: Ciência e Profissão, 30(3), 492-503. doi:10.1590/S1414-98932010000300005

Asamani, A. L., \& Mensah, O. (2013). To what extent does employees perception of organizational justice influence their organizational citizenship behaviour? European Journal of Business and Management, 5(16), 32-41.

Bastos, A. V. B., Siqueira, M. M. M., \& Gomes, A. C. P. (2014). Cidadania organizacional. In M. M. M. Siqueira (Ed.), Novas medidas do comportamento organizacional: Ferramentas de diagnóstico e gestão (pp. 79-103). Porto Alegre, RS: Artmed. 
Batista, L. R., \& Oliveira, A. F. (2012). Antecedentes da confiança do empregado na organização. Estudos de Psicologia (Natal), 17(2), 247-254. doi:10.1590/S1413-294X2012000200008

Carvalho, V. D., Oliveira, T. A., \& Silva, D. C. (2013). Valores organizacionais em instituições públicas brasileiras: Percepções dos servidores em diferentes posições hierárquicas e tipos de entidade de administração indireta. Revista de Administração Mackenzie, 14(5), 74-103.

Cavazotte, F., Hartman, N. S., \& Bahiense, E. (2013). Charismatic leadership, citizenship behaviors, and power distance orientation: Comparing Brazilian and U.S. Workers. Cross-Cultural Research, 48(1), 3-31. doi:10.1177/1069397113494687

Chhetri, P. (2014). The role of cognitive and affective trust in the relationship between organizational justice and organizational citizenship behavior: A conceptual framework. Business: Theory and Practice, 15(2), 170-178. doi:10.3846/ btp. 2014.17

Cummings, L. L., \& Bromiley, P. (1996). The organizational trust inventory. In R. M. Kramer \& T. R. Tyler (Eds.), Trust in organizations. Frontiers of theory and research (pp. 302-330). Thousand Oaks, CA: Sage.

Dolan, S. L., Tzafrir, S. S., \& Baruch, Y. (2005). Testing the causal relationships between procedural justice, trust and organizational citizenship behavior. Revue de Gestion des Resources Humaines, 14(10), 79-89.

Drummond, V. S. (2007). Confiança e liderança nas organizações. São Paulo, SP: Thomson Learning.

Estivalete, V. F. V., Andrade, T., Gomes, T. C., \& Costa, V. F. (2012). Valores organizacionais no Brasil: Uma análise da produção científica na área da administração nos últimos 10 anos. Gestão Contemporânea, 9(12), 43-68.

Ferreira, M. C., \& Fernandes, H. A. (2009). O impacto dos valores pessoais e organizacionais no comprometimento com a organização. Psico-USF, 14(3), 341-354. doi:10.1590/S141382712009000300010

Ferrin, D. L., Bligh, M. C., \& Kohles, J. C. (2007). Can I trust you to trust me? A theory of trust, monitoring, and cooperation in interpersonal and intergroup relationships. Group \& Organizational Management, 32(4), 465-499. doi:10.1177/1059601106293960
Guardani, F., Teixeira, M. L. M., Bido, D. S., \& Mazzon, J. A. (2013). A relação entre valores, práticas organizacionais e confiança de clientes no setor de serviços. Produção, 23(4), 806-817. doi:10.1590/S0103-65132013005000019

Hair, J. F., Anderson, R. E., Tatham, R. L., \& Black, W. C. (2005). Análise multivariada de dados. Porto Alegre, RS: Bookman.

Hakim, W., Nimram, U., Haerani, S., \& Alam, S. (2014). The antecedents of organizational citizenship behavior (OCB) and their effect on performance: Study on public university in Makassar, South Sulawesi, Indonesia. Journal of Business and Management, 16(2), 5-13.

Hassan, A. (2007). Human resource development and organizational values. Journal of European Industrial Training, 31(6), 435-448.

Hassan, M., \& Semerciöz, F. (2010). Trust in personal and impersonal forms its antecedents and consequences: A conceptual analysis within organizational context. International Journal of Management and Information Systems, 14(2), 67-83. doi:10.19030/ijmis.v14i2.832

Horta, P., Demo, G., \& Roure, P. (2012). Políticas de Gestão de Pessoas, confiança e bem-estar no trabalho: Estudo em uma multinacional. Revista de Administração Contemporânea, 16(4), 566-585. doi:10.1590/S1415-65552012000400005

Ianaguivara, C. A. (2011). Confiança do empregado na organização: Revalidação de instrumento de medida (Master's thesis, Instituto de Psicologia, Universidade Federal de Uberlândia, MG, Brazil)

Jardim, M. F. (2009). Valores organizacionais $e$ civismo no Sistema Judiciário Mineiro (Master's thesis, Faculdade Novos Horizontes, Belo Horizonte, MG, Brazil).

Kashani, F. H. (2012). A review on relationship between quality of work life and organizational citizenship behavior (Case Study: An Iranian Company). Journal of Basic and Applied Scientific Research, 2(9), 9523-9531.

Katz, D., \& Kahn, R. L. (1974). Psicologia social das organizações. São Paulo, SP: Atlas.

Kramer, R. M. (1999). Trust and distrust in organizations: Emerging perspectives, enduring questions. Annual Review of Psychology, 50(1), 569-598. doi:10.1146/annurev.psych.50.1.569 
Leat, M., \& El-Kot, G. (2009). Interpersonal trust at work, intrinsic motivation, work-related tension and satisfaction in Egypt. International Journal of Workplace Health Management, 2(2), 180194. doi:10.1108/17538350910970237

Lee, U. H., Kim, H. K., \& Kim, Y. H. (2013). Determinants of organizational citizenship behavior and its outcomes. Global Business \& Management Research: An International Journal, 5(1), 54-65.

Miles, J., \& Schevlin, M. (2001). Applying regression \& correlation. A guide for students and researchers. London: Sage.

Moorman, R. H. (1991). Relationship between organizational justice and organizational citizenship behaviors: Do fairness perceptions influence employee citizenship? Journal of Applied Psychology, 76(6), 845-855.

Moorman, R. H., \& Blakely, G. L. (1995). Individualism-collectivism as an individual difference predictor of organizational citizenship behavior. Journal of Organizational Behavior, 16(2), 127 142. doi:10.1002/job.4030160204

Nienaber, A. M., Hofeditz, M., \& Searle, R. H. (2014). Do we bank on regulation or reputation? A meta-analysis and meta-regression of organizational trust in the financial services sector international. Journal of Bank Marketing, 32(5), 367-407. doi:10.1108/IJBM-12-2013-0146

Novelli, J. G., Fischer, R. M., \& Mazzon, J. A. (2006). Fatores de confiança interpessoal no ambiente de trabalho. Revista Administração, 41(4), 442452. doi:10.1590/S0080-21072006000400008

Oliveira, A. F. (2004). Confiança do empregado na organização: Impacto dos valores pessoais, organizacionais e da justiça organizacional (Doctoral dissertation, Instituto de Psicologia, Universidade de Brasília, DF, Brazil).

Oliveira, A. F., \& Gomide, S., Jr. (2012). Valores, confiança do empregado e bem-estar subjetivo. In H. Mendonça (Ed.) Saúde e bem-estar no trabalho: Dimensões individuais e culturais (pp. 203-228). São Paulo, SP: Casa do Psicólogo.

Oliveira, A. F., \& Souza, M. A. (2014). Confiança do empregado na organização: $O$ impacto dos valores pessoais e organizacionais. Revista Psicologia: Organizações e Trabalho, 14(2), 204-217.

Oliveira, A. F., \& Tamayo, A. (2004). Inventário de perfis de valores organizacionais. Revista de
Administração da Universidade de São Paulo, 39(2), 129-140.

Oliveira, A. F., \& Tamayo, A. (2008). Confiança do empregado na organização. In M. M. M. Siqueira (Ed.), Medidas do comportamento organizacional: Ferramentas de diagnóstico e de gestão (pp. 97-109). Porto Alegre, RS: Artmed.

Organ, D. W. (1990). The motivational basis of organizational citizenship behaviour. Research in Organizational Behaviour, 12, 43-72.

Organ, D. W., Podsakoff, P. M., \& MacKenzie, S. B. (2006). Organizational citizenship behavior: Its nature, antecedents, and consequences. London: Sage.

Ozer, M. (2011). A moderated mediation model of the relationship between organizational citizenship behaviors and job performance. Journal of Applied Psychology, 96(6), 1328-1336. doi:10.1037/a0023644

Podsakoff, N. P., Whiting, S. W., Podsakoff, P. M., \& Blume, B. D. (2009). Individual- and organizational-level consequences of organizational citizenship behaviors: A meta-analysis. Journal of Applied Psychology, 94(1), 122-141. doi:10.1037/a0013079

Podsakoff, N. P., Whiting, S. W., Podsakoff, P. M., \& Mishra, P. (2011). Effects of organizational citizenship behaviors on selection decisions in employment interviews. Journal of Applied Psychology, 96(2), 310-326. doi:10.1037/a0020948

Porto, J. B., \& Tamayo, A. (2003). Desenvolvimento e validação da Escala de Civismo nas Organizações. Estudos de Psicologia (Natal), 8(3), 393402. doi:10.1590/S1413-294X2003000300006

Porto, J. B., \& Tamayo, A. (2005). Valores organizacionais e civismo nas organizações. Revista de Administração Contemporânea, 9(1), 35-52. doi:10.1590/S1415-65552005000100003

Purohit, B., Patel, D., \& Purohit, S. (2014). A study of organizational values in government run primary health centres in India. Journal of Health Management, 16(2), 303-313. doi:10.1177/0972063414526119

Rapp, A. A., Bachrach, D. G., \& Rapp, T. L. (2013). The influence of time management skill on the curvilinear relationship between organizational citizenship behavior and task performance. Journal of Applied Psychology, 98(4), 668-677. doi:10.1037/a0031733 
Rauf, F. H. A. (2014). Perception of organizational justice as a predictor of organizational citizenship behavior: An empirical study at schools in Sri Lanka. European Journal of Business and Management, 6(12), 124-130.

Silva, N., \& Zanelli, J. C. (2014). Cultura organizacional. In J. C. Zanelli, J. E. Borges-Andrade, \& A. V. B. Bastos (Eds.), Psicologia, organizações e trabalho no Brasil (pp. 491-546). Porto Alegre, RS: Artmed.

Siqueira, M. M. M. (1995). Antecedentes do comportamento de cidadania organizacional: A análise de um modelo pós-cognitivo (Doctoral dissertation, Instituto de Psicologia, Universidade de Brasília, DF, Brazil).

Siqueira, M. M. M., \& Gomide, S., Jr. (2014). Vínculos do indivíduo com o trabalho e com a organização. In J. C. Zanelli, J. E. Borges-Andrade, \& A. V. B. Bastos (Eds.), Psicologia, organizações e trabalho no Brasil (pp. 316-328). Porto Alegre, RS: Artmed.

Song, J. H., \& Kim, H. M. (2009). The integrative structure of employee commitment: The influential relations of individuals' characteristics in a supportive learning culture. Leadership \& Organizational Development Journal, 30(3), 240255. doi:10.1108/01437730910949526

Spitzmüller, M., Van Dyne, L., \& Remus, I. (2008). Organizational citizenship behavior: A review and extension of its nomological network. In J. Barling \& C. L. Cooper, The Sage Handbook of Organizational Behavior: Vol. 1. Micro approaches (pp. 106-123). London: Sage.
Tabachnick, B. G., \& Fidell, L. S. (2001). Using multivariate statistics. New York: Allyn and Bacon.

Tamayo, A. (2007). Contribuições ao estudo dos valores pessoais, laborais e organizacionais [Special isue]. Psicologia: Teoria e Pesquisa, 23, 17-24. doi:10.1590/S0102-37722007000500004

Tamayo, A. (2008). Valores organizacionais. In M. M. M. Siqueira (Ed.), Medidas do comportamento organizacional: Ferramentas de diagnóstico e de gestão (pp. 309-340). Porto Alegre, RS: Artmed.

Tamayo, A., \& Gondim, M. G. C. (1996). Escala de valores organizacionais. Revista de Administração da Universidade de São Paulo, 31(2), 62-72.

Zanini, M. T., Lusk, E., \& Wolff, B. (2009). Confiança dentro das organizações da nova economia: Uma análise empírica sobre as consequências da incerteza institucional. Revista Administração Contemporânea, 13(1), 72-91. doi:10.1590/ S1415-65552009000100006

Recebido: 03/02/2015

$1^{a}$ revisão: $31 / 07 / 2015$

$2^{a}$ revisão: 03/09/2015

Aceite final: 10/09/2015 